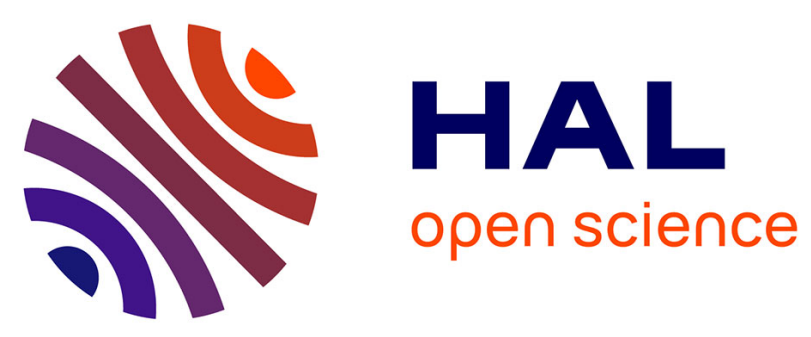

\title{
Density of magmas at depth
}

Chrystèle Sanloup

\section{- To cite this version:}

Chrystèle Sanloup. Density of magmas at depth. Chemical Geology, 2016, 429, pp.51-59. 10.1016/j.chemgeo.2016.03.002 . hal-01285394

\section{HAL Id: hal-01285394 https://hal.sorbonne-universite.fr/hal-01285394}

Submitted on 9 Mar 2016

HAL is a multi-disciplinary open access archive for the deposit and dissemination of scientific research documents, whether they are published or not. The documents may come from teaching and research institutions in France or abroad, or from public or private research centers.
L'archive ouverte pluridisciplinaire HAL, est destinée au dépôt et à la diffusion de documents scientifiques de niveau recherche, publiés ou non, émanant des établissements d'enseignement et de recherche français ou étrangers, des laboratoires publics ou privés. 


\title{
Density of magmas at depth
}

Chrystèle Sanloup

Sorbonne Universités, UPMC Univ Paris 06, CNRS, Institut des Sciences de la Terre de Paris (iSTeP), 4 place Jussieu 75005 Paris, France

\begin{abstract}
Knowing the density of silicate liquids at high pressure is essential to answer questions relevant to the presence of magmas at depth, whether that be in the present Earth or in its earliest times, during differentiation of the planet. Melts have unique physical and chemical properties, which vary as a function pressure, and chemical composition. The focus here will be on in situ measurements of the density of magmas, with a presentation of the available methods and of the main results obtained so far, including why some magmas may be trapped at depth. Understanding the macroscopical physical properties of magmas requires an accurate microscopic structural description. Structural descriptions of compressed magmas are becoming more widely available, from experiments and from theoretical calculations. These structural inputs are used to understand the compression mechanisms at stake in the densification of magmas, e.g. the collapse of voids, coordination increase for the major cations, and bond compressibility. These densification processes profoundly affect not only the physical properties of the melt, but also its chemical properties, i.e. the way elements partition between the magma and a metallic melt or between the magma and crystals.
\end{abstract}

Keywords: magmas, density, silicate melts, high pressure, element partitioning, density traps

\section{Introduction}

Magmas are essentially high pressure $(P)$ objects, being formed at depth. Magmas that erupt on the surface were formed mostly below mid-oceanic ridges between 30 and $50 \mathrm{~km}$ depth (Lee et al., 2009)), between 100 and $150 \mathrm{~km}$ depth at subduction ones (Syracuse and Abers, 2006; Schmidt and S.Poli, 2014), and down to $220 \mathrm{~km}$ for komatiite melts (Lee et al., 2009). In 
addition, seismology has probed discrete zones at depth where the presence of magmas is suspected: at the lithosphere-asthenosphere boundary (Schmerr, 2012), atop the $410 \mathrm{~km}$ (Tauzin et al., 2010) and $660 \mathrm{~km}$ (Schmandt et al., 2014) discontinuities, and in the ultra-low velocity zones (ULVZ) atop the core-mantle boundary (Williams and Garnero, 1996). The discrete depths at which magmas are detected raise the question of why they are trapped and/or produced only there. For the magmas that reach the surface, knowing their density vs $P$ is essential to model their behaviour from segregation from the parent rock and consequent control on melt composition, to their ascent to the surface (Stolper et al., 1981). Magmas are ubiquitous objects in the solar system, both currently on the surface of terrestrial planets and some satellites (e.g. Io, the Moon), and in the past as planets were born molten (Harper, 1996). The structure of planets as we know them now has thus been inherited from this molten era, the magma ocean stage, although the extent in space and time of the magma ocean are a matter of debate (see Carlson et al. (2014) and Elkins-Tanton (2012) for reviews on the topic). Matter and heat were transferred through the magma ocean either to the surface or to the core of planets, density exerting a first order control on these differentiation processes.

The compressibility of magmas has been measured extensively at ambient pressure using ultrasonic techniques (cf Rivers and Carmichael (1987); Lange and Carmichael (1987); Ai and Lange (2008) and references therein), resulting in a comprehensive data-set. Pioneering high $P$ density measurements on magmas were obtained with shock-wave techniques up to $23 \mathrm{GPa}$ (Rigden et al., 1984), verifying the prediction of a density cross-over between melts and co-existing crystals (Stolper et al., 1981). The existence of melts/crystals cross-over(s) imply that magmas may be trapped at depth, eventually leading to the formation of hidden reservoirs enriched in incompatible elements. This major result has been confirmed by static high $P-T$ sink-float measurements (Agee, 1998). The sink-float method has been successfully applied to different basic and ultrabasic melts (see Ohtani (2009) for a review of the method). The highest achievable pressures with this method have been reached using diamond markers (Suzuki et al., 1995; Sakamaki et al., 2006) and have revealed that diamond may float in the transition zone (Suzuki et al., 1995). The sink-float method is restricted to low viscosity melts in order for the sphere to fall, i.e. basic and ultrabasic melts. Different markers may be used: olivine, garnet and diamond, so that up to 4 to 5 points can be collected along the equation of state up to a maximum of $24 \mathrm{GPa}$. Based on 
these high $P$ data and the ultrasonic ambient $P$ data, thermodynamic models have been built to calculate the density of any magma under $P$ from the partial molar volumes of the constituent oxide components (Ghiorso, 2004).

With the advancement of x-ray synchrotron sources at the beginning of the century, measuring the properties of compressed non-crystalline materials such as melts became possible using different methods presented below. A main advantage of in situ methods is the unequivocal melting criterium with the concomitant disappearance of crystalline Bragg peaks and the appearance of a diffuse scattered signal on x-ray diffraction data. These techniques thus avoid relying on the interpretation of quench textures to assess melting that can be ambiguous for ultrabasic compositions that do not quench as glasses. Additionally, in situ methods may combine several approaches within the same experimental set-up, such as viscosity, ultrasonic, and structural measurements (Kono et al., 2014).

The outline of this paper is to first present the different in situ X-ray synchrotron based methods to measure the density of magmas at high $P$, their $P-T$ domains of application, and their pros and cons compared to other methods. Next, the compression mechanisms at stake in magmas at depth will be discussed as a function of the pressure range at which they occur. This discussion will be closely based on the structural evolution of silicate melts, with inputs from both experiments and theory. Lastly, planetary implications will be discussed. Densification of magmas may imply their segregation at depth for some particular compositions and in some particular planetary contexts. Densification may also affect the way elements partition between crystals and silicate melts, or between metallic and silicate melts.

\section{How to measure the density of magmas at depth}

This section highlights the pros and cons of the different in situ methods that have been developed to measure the density of magmas at high pressures, along with their domains of application in terms of pressure, temperature and chemical compositions.

\subsection{In situ X-ray absorption}

The x-ray absorption was initially developed to measure the density of relatively heavy metallic melts such as indium using large volume presses (Katayama et al., 1996, 1998), but was successfully applied later to liquid phosphorous (Katayama et al., 2004). The x-ray absorption method (Fig.1) 
consists in measuring the intensity of the x-ray beam that is absorbed by the sample while scanning the press perpendicularly to the x-ray beam. The beam intensity is recorded using photodiodes or ionisation chambers, typically within 20-30 minutes to have an adequate signal vs noise ratio. Each absorption scan is simulated with relation (1) leading to values of $(\mu \rho)_{l i q}$.

$$
\frac{I}{I_{o}}=\int_{x, y} \exp \left(-(\mu \rho d)_{l i q}-(\mu \rho d)_{e n v}\right) d x d y
$$

where $\mu$ is the mass absorption coefficient, $\rho$ the density, $d$ the X-ray path length and $y$ the vertical size of the X-ray beam (typically $50 \mu \mathrm{m}$ width $\times$ $50 \mu \mathrm{m}$ height). The subscript env stands for the environment surrounding the sample. The sample absorption coefficient, $\mu(E)$ ( $E$ is the energy of the x-ray beam), must be either known or ideally measured for instance on the crystalline sample which density can be measured by in situ x-ray diffraction. This method allows to cover a fine $P-T$ mesh, it is not restrictive in terms of chemical compositions, and in the case of magmas, it allowed to measured the density of very siliceous compositions that could not be studied using the sink-float method. The energy of the beam may be tuned to optimize the $\rho \mu_{\text {sample }} / \rho \mu_{\text {env }}$. ratio, with higher energies better suited to heavy (i.e. high mean atomic number) materials. In the case of molten silicates, the optimum container is single crystal diamond cylinder, combining a very low absorption background with a minimal shape deviation, and limited chemical reactivity. Limited carbon dissolution may happen, either as reduced carbon or as carbonates (Crépisson et al., 2014). $P$ is not transmitted through the diamond capsule walls, but through the caps, that must therefore be made of softer materials, either graphite or metal foil (platinum-rhodium or rhenium), the latter being more appropriate for volatile-containing compositions as the foil seals the capsule under high $P$. $P$ transmission is then achieved only at high $T$ though, above $1200 \mathrm{~K}$ (Van Kan Parker et al., 2010).

The main draw-back of the x-ray absorption method using large volume presses is that the sample must be surrounded by low $\mathrm{Z}$ materials in order to have a good absorption contrast between the sample and its environment $\left(\rho \mu_{\text {sample }} / \rho \mu_{\text {env. }}\right)$, thus restricting measurements to relatively low pressures $(<10 \mathrm{GPa})$. Indeed, the consequences of a low $\mathrm{Z}$ cell assembly, typically consisting of a boron-epoxy gasket directly in contact with the graphite heater as any thermal insulator would be a too high x-ray absorber, are its instability at very high temperatures and weak resistance to flow. The cell-assembly 


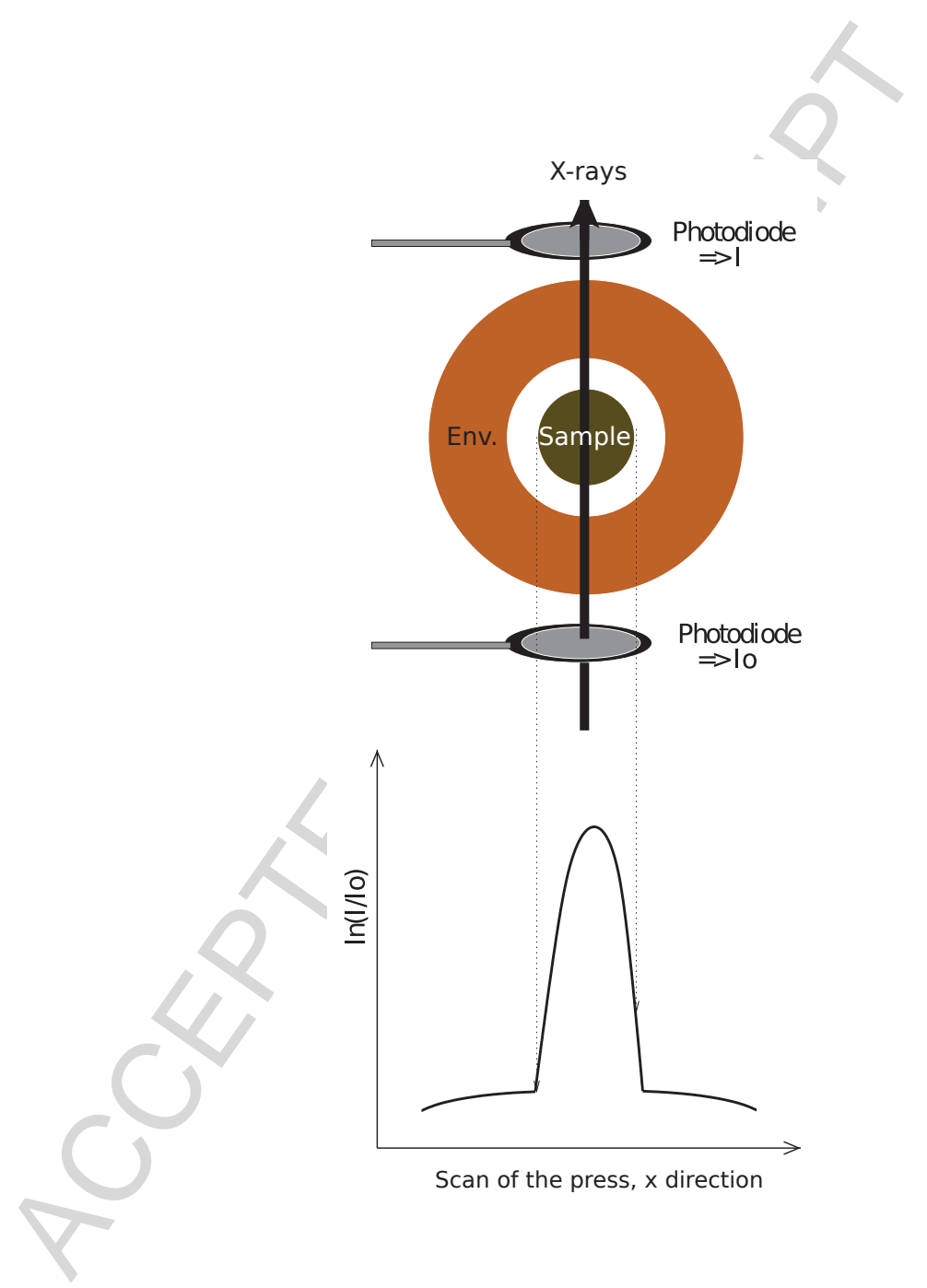

Figure 1: Schematic of the x-ray absorption method.

therefore flattens which restricts measurements to below 10 GPa. The xray absorption method has been adapted to diamond anvil cells for liquid indium (Shen et al., 2002), and lately up to $100 \mathrm{GPa}$ on silica glass (Sato and Funamori, 2010), but has not yet been used for silicate melts.

Earth sciences applications using large volume presses were initially done 
on molten Fe and its alloys (Sanloup et al., 2000, 2004, 2011), then extended to silicate melts of various compositions: rhyolite (Malfait et al., 2014b), andesite (Malfait et al., 2014a), phonolite (Seifert et al., 2013), basalt (Sakamaki et al., 2013), alkali basalt (Crépisson et al., 2014), lunar basalts (Sakamaki et al., 2010b; Van Kan Parker et al., 2012), dry peridotite (Sakamaki et al., 2010a), hydrous peridotite (Sakamaki et al., 2009), carbonated peridotite (Sakamaki et al., 2011). The greater precision and higher coverage in terms of $P-T$ space allowed to resolve crust-related issues: the settling rate of crystals in the magma chamber could be measured and residence times constrained (Seifert et al., 2013), and magma buoyancy in the crust was found to be sufficient to trigger super-eruptions (Malfait et al., 2014b). From the combination of in situ density and viscosity measurements, it was suggested that molten basalts may be stagnant at the oceanic lithosphere-asthenosphere boundary due to a decrease in the $\Delta \rho / \nu$ ratio $\left(\Delta \rho=\rho_{\text {surrounding }}\right.$ rocks $-\rho_{\text {magma }}$ where $\nu$ is the viscosity and $\rho$ the density) that controls vertical mobility of melts (Sakamaki et al., 2013).

\subsection{In situ $X$-ray diffraction}

\subsubsection{Obtaining density from the radial distribution function}

The main result that one can obtain from diffraction is the local structure, described by the radial distribution function $G(r)$, itself obtained by Fourier Transform of the scaled scattered intensity, i.e. the form factor $S(q)$. According to equation 2 , the average atomic density $n_{0}$ can be obtained by minimizing the artificial oscillations below the first peak, i.e. where there should be no atomic contribution to $G(r)$.

$$
G(r)=\left(n(r)-n_{0}\right) \int_{0}^{q_{\max }} q\left(S(q)-S_{\infty}\right) \sin (q r) d q
$$

where $n(r)$ is the atomic density in atoms per volume unit at a radial distance $r$, and $n_{0}$ its average value that is related to the macroscopic density $\rho$ through $n_{0}=\frac{\rho}{M \mathcal{N}_{A}}$ with $M$ the mean molecular mass, and $\mathcal{N}_{A}$ the Avogadro number. The minimum interatomic distance, $r_{\min }$ must be defined with care and should not overlap with the distribution of distances for the first peak on the low $r$ side. These oscillations at low distances arise mostly from normalization and form factor errors (Kaplow et al., 1965), plus background removal errors if the sample is surrounded by an environment such as a cell-assembly if using a large volume press, or diamond anvils if using a diamond anvil cell. 
This environment contribution being usually on a large $q$-range, its Fourier Transform contributes mostly to the signal at very low distances, i.e. where density may be determined. The environment signal must either be filtered or removed. Filtering can be done by using energy-dispersive diffraction as the parallelogram of diffraction is defined by the intersection between the incident x-ray beam and the section defined by the entrance slits on the detector at a given angle. If using angle-dispersive diffraction, multi-channels collectors can be used, the slits being located on a rotating axis centered on the sample position (Yaoita et al., 1997; Mezouar et al., 2002). Alternatively, the environment signal can be removed by collecting x-ray data with no contribution from the molten sample. That can be done on the sample in the crystalline state by fitting the background, and/or by collecting data on an empty gasket, ideally the one that contained the molten sample once emptied and put back in place in the diamond anvil cell. If using a large volume press, the environment signal can be obtained by moving the press so that the x-ray beam goes just outside of the sample. The obtained pattern can then be scaled to match the background of the crystalline pattern, without the need for crystalline peaks removal.

However, either filtering or removing the environment signal is often not perfect, and some signal remains. It usually does not affect the structural interpretation of $G(r)$, but does affect density measurements. Diamond anvils in particular have a strong inelastic contribution to the signal (Compton scattering) which makes the process of removing sample environment signal much more difficult than for large volume experiments (Fig.2). Self-consistent minimization procedures are efficient in fully removing the background signal as first demonstrated on liquid mercury at ambient $P$ (Kaplow et al., 1965), and later on water compressed in a diamond anvil cell (Eggert et al., 2002). Additional constraints may help, such as considering that $\lim _{q \rightarrow 0} S(q)=$ $\frac{n T k_{B}}{K_{T}}=0$ at high degrees of compression (Sanloup et al., 2008), or in other words that $S(q)$ is less than the experimental noise at low $q$, typically 0.02 for thin laser-heated samples. This value is reached above $40 \mathrm{GPa}$ for silicate melts.

\subsubsection{Deriving compressibility from the structure factor}

At low degrees of compression, the value of $S(0)$ can be derived from extrapolating low $q$ signal to zero (Sanloup et al., 2013a). Energy dispersive x-ray diffraction is better suited for this approach due to the higher signal/noise ratio that can be reached at low $q$ on the lowest angles spec- 

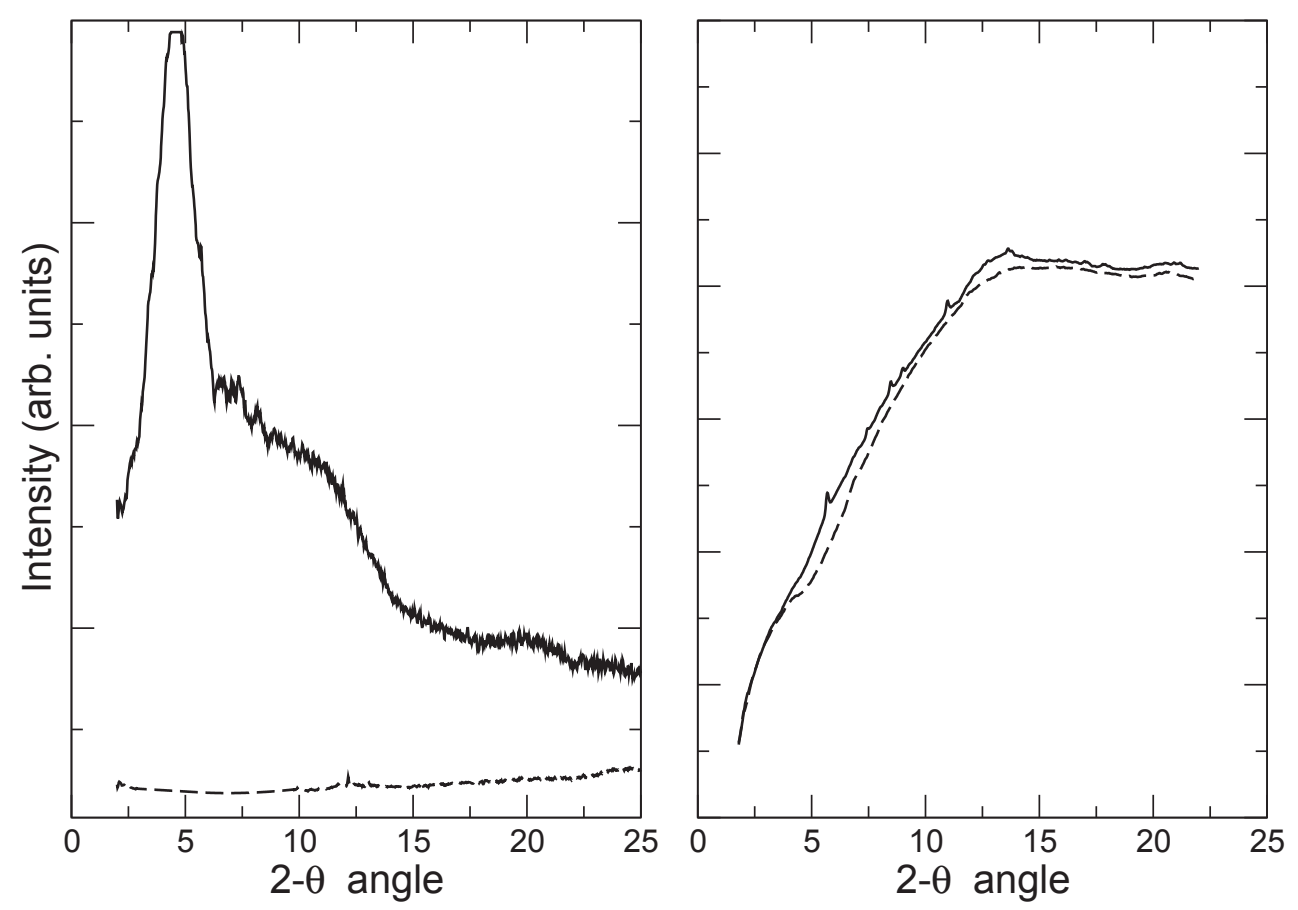

Figure 2: Intensity scattered by compressed molten basalt (plain curve) compared to the environment signal (dashed curve). Left panel: molten basalt at 3.9 GPa using a ParisEdinburgh press (data from Crépisson et al. (2014)). Right panel: molten basalt at 24.6 GPa using laser-heated diamond anvil cell (data from Sanloup et al. (2013b), small Bragg peaks come from the $\mathrm{SiO}_{2} P$-transmitting medium).

tra (noise typically below 0.002 ) within reasonable acquisition times hence allowing extrapolations down to zero. From

$$
\lim _{q \rightarrow 0} S(q)=\frac{n T k_{B}}{K_{T}}
$$

and

$$
\left.K_{T}=\rho \frac{\partial P}{\partial \rho}\right)_{T},
$$


we obtain

$$
\left.\frac{\partial P}{\partial \rho}\right)_{T}=\frac{\mathcal{N}_{A} k_{B} T}{M S(0)}
$$

where $k_{B}$ is the Boltzmann constant, $\mathcal{N}_{A}$ is the Avogadro number, and $K_{T}$ the isothermal bulk modulus. Equation 5 is valid for any isotropic liquid (Egelstaff, 1994) and is independent of the nature of bonding within the melt. Densities at high pressure can be calculated from a starting point at which density is known by determining $(\partial P / \partial \rho)_{T}(P)$ at each point and propagating it.

Only the self-consistent diffraction-based technique is compatible with the use of laser-heated diamond-anvil cells and the larger $P-T$ range they may cover. Another major advantage of this technique is that it provides local structural insights to interpret compression mechanisms, at least on the 6-8 $\AA$ scale that is accessible by x-ray diffraction.

\subsection{Pros and cons of different methods}

Table 1 summarizes the different techniques mentioned above, their domains of applications, and their main advantages/disadvantages. Aside from shock-waves, all techniques presented are compatible with large volume presses, while the x-ray diffraction method is compatible both with large volume presses and laser-heated diamond anvil cells.

\begin{tabular}{|c|c|c|c|}
\hline Technique & $\begin{array}{l}P-T \text { range } \\
\& \text { technique }\end{array}$ & Pros & Cons \\
\hline Shock-wave & $3000 \mathrm{~K}$ & undefeated $P$ range & $T$ correction might be an issue \\
\hline Sink-float & $\begin{array}{l}24 \underset{\mathrm{GPa}-2500 \mathrm{~K}}{\mathrm{LVP}} \\
\end{array}$ & straightforward diagnostic & $\begin{array}{l}\text { only basic-ultrabasic compositions } \\
\text { few points along the EoS }\end{array}$ \\
\hline X-ray absorption & $\begin{array}{l}10 \mathrm{GPa}-2300 \mathrm{~K} \\
\mathrm{LVP}\end{array}$ & $\begin{array}{l}\text { fine } P-T \text { mesh, } \\
\text { relatively straightforward diagnostic } \\
\text { compatible with other in situ diagnostics }\end{array}$ & $\begin{array}{l}\text { cell instability, } \\
\text { relatively small } P \text { range }\end{array}$ \\
\hline $\mathrm{X}$-ray diffraction & $\begin{array}{l}70 \mathrm{GPa}-3000 \mathrm{~K} \\
\text { LVP and DAC }\end{array}$ & $\begin{array}{l}\text { fine } P-T \text { mesh } \\
\text { simultaneous structural data }\end{array}$ & $\begin{array}{l}\text { delicate data processing } \\
\text { challenging experiments }\end{array}$ \\
\hline
\end{tabular}

Table 1: Comparison between different methods to measure the density of magmas at high pressure. ${ }^{*}$ The indicated $P-T$ range corresponds to the maximum values reached in the literature. LVP stands for large volume press, DAC stands for diamond anvil cell.

An issue not yet tackled in this section is that of chemical contamination. Chemical contamination is an issue for all experimental techniques presented here. Indeed, silicates have a high melting point, often challenging 
to reach and maintain over the course of the measurements. Chemical reactions with the surrounding materials may be limited, but they are unavoidable as there is always a $P$-containing medium. This $P$-containing medium can be a molybdenum container in shock-waves experiments, a molybdenum or graphite capsule for sink-float experiments, a diamond capsule and $\mathrm{Pt} / \mathrm{Re}$ or graphite caps for x-ray absorption experiments, thermal insulation layers (e.g. silica glass) for laser heated-diamond anvil cells experiments although reaction can be limited for the latter by using a focussed laser, not ramped but shot directly at the required high power and for a short acquisition time (1 second or less). Reaction may also occur with the density marker in sinkfloat experiments. Whenever recovery of the sample is possible after the experiment, it is therefore best to analyze the samples post mortem and estimate the necessary corrections to be applied due to chemical contamination.

\section{Compression Mechanisms}

As liquids, magmas have more compression mechanisms available than their crystalline counterparts. Molten basalt density is available from the full range of methods (sink-float, shock-waves, X-ray absorption, X-ray diffraction), its petrological relationships under pressure are well described, including the density of crystalline basalt (i.e. eclogite). Basalt is also the most commonly produced magma in the current-day Earth (>90\% of the melts reaching the surface). It is so far the only natural magma for which both density and structure have been measured to mid-mantle depths. For all these reasons, this section will largely rely on the compression mechanisms in molten basalt, and enlarging to other compositions whenever data are available. Fig. 3 summarizes the experimental and theoretical density data for molten basalt and its chemical Fe-free analogue (36\%anorthite-64\%diopside). Molten basalt is initially very compressible, much more than eclogite, in what will be called below the 'low pressure domain' (section 3.1). In contrast, above $35 \mathrm{GPa}$ and up to the highest $P$ investigated, the density of molten basalt is very close to that of crystallized basalt within the experimental error bars (section 3.3). In between these two extreme $P$ domains, molten basalt stiffens progressively, and the main cations undergo coordination number increase (section 3.2). Each of these three domains is controlled by a particular compression mechanism, and only high order equation of states (above third order) may fit all density measurements up to the highest pressures (Asimow and Ahrens, 2010; Sanloup et al., 2013b). An important issue thus to 
be raised is that such $4^{\text {th }}$ or $5^{\text {th }}$ equation of state only has a mathematical meaning as a fit to the data in a given $P$-range, but does not have a physical meaning since it encompasses different structural changes over different and partially overlapping $P$-domains.

Interestingly, a similar analysis has been postulated for silica from the observed glass behavior (Wakabayashi and Funamori, 2013). Over the 0-60 GPa range, silica melt first transforms to a densified melt (equivalent of the quartz to coesite transition but smoothed over a larger $P$-range), then SiO coordination number increases from 4 to 6 , after which silica melt has a stishovite-like behavior.

\subsection{Low pressure domain $(<5 G P a)$}

Compression of silicate magmas over the lowest pressure domain (0-5 $\mathrm{GPa}$ ) is dominated by the collapse of topological voids and their disappearance by $5 \mathrm{GPa}$, as the packing limit of tetrahedral structural units is reached (Ai and Lange, 2008; Wang et al., 2014). If the distance between a given point in space and any atom exceeds $2.5 \AA$, it can be defined as a cavity or void (Kohara et al., 2011). Topological voids are induced by melt polymerization, their concentration is highest in silica melt and null in olivine melts. Polymerization of tetrahedral $\mathrm{SiO}_{2}$ units results in a broad distribution of rings, unlike the characteristic 6-membered rings of crystalline quartz or the 4-membered rings of crystalline anorthite for instance.

This first compression stage can be tracked by following the first sharp diffraction peak (FSDP) on the structure factor, $S(q)$ where $q$ is the scattering vector, obtained by normalizing x-ray diffraction data. The FSDP is an indicator of the intermediate range order in non-crystalline materials. It is linked to density oscillations of periodicity $2 \pi / q_{\max }$, where $q_{\max }$ is the position of the FSDP (Salmon, 1994), which in the case of silicate melts may be associated with the voids population. This periodicity ranges from a minimum of $4.2 \AA$ for $\mathrm{SiO}_{2}$ glass room $P$ down to $2.86 \AA$ for molten basalt at $5 \mathrm{GPa}$. The position of the FSDP shifts rapidly with pressure up to 5 $\mathrm{GPa}$ (Fig.4), and especially in the first $2 \mathrm{GPa}$. This rapid shift illustrates the collapse of voids, likely related to the diffusion of $\mathrm{SiO}_{2}$ tetrahedral units under pressure. It is indeed noteworthy that viscosity similarly decreases with pressure in the $0-5 \mathrm{GPa}$ range but mostly within the first $2 \mathrm{GPa}$. This is the case for all silicate melts though much more markedly for siliceous compositions (see Wang et al. (2014) and Spice et al. (2015) for a compilation of viscosity measurements on magmas). This first compression regime is 


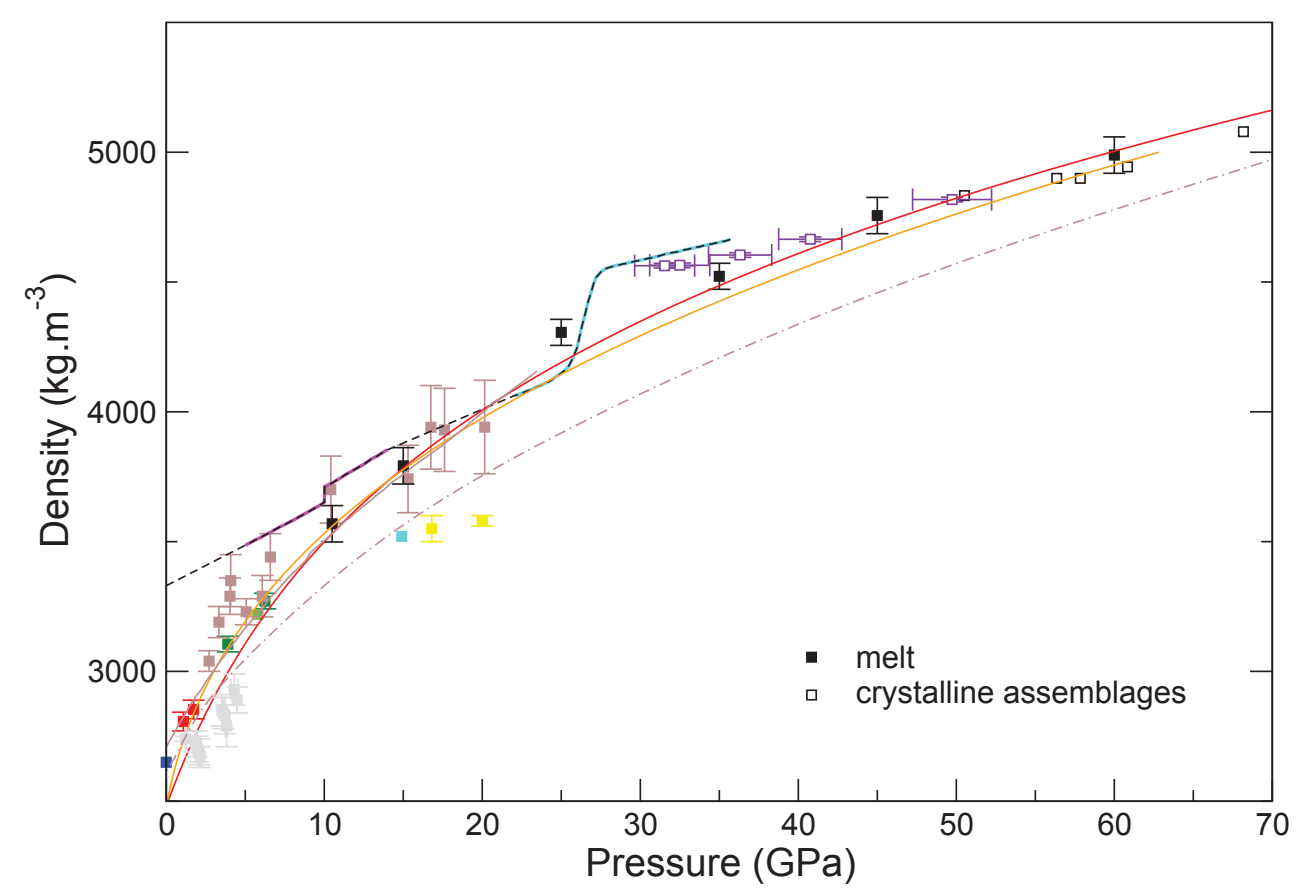

Figure 3: Density of molten basalt (full symbols) obtained by different methods compared to the density of crystalline basalt (empty symbols). Experimental data on melts: dark green squares (x-ray absorption, Crépisson et al. (2014)), grey squares (x-ray absorption, Sakamaki et al. (2013)), red (sink-float, 1673 K, Fujii (1978)), light green square (sink-float, 1673 K, Agee (1998)), light blue square (sink-float, 2573 K, Ohtani and Maeda (2001)), yellow squares (sink-float, $\mathrm{T}=2473-2573 \mathrm{~K}$, Sakamaki et al. (2010a)), black squares (Xray diffraction, $2735 \mathrm{~K}$, Sanloup et al. (2013b)), brown squares (shock-wave isentrope, $\mathrm{T}_{0}=1673 \mathrm{~K}$, Rowan (1993)), brown curve (shock-wave, compression of $\mathrm{An}_{3} 6-\mathrm{Di}_{6} 4$ applied to basalt, Rigden et al. (1984)), dot dash brown line (shock-waves, compression of $\mathrm{An}_{3} 6$ $\mathrm{Di}_{6} 4$ applied to basalt, Asimow and Ahrens (2010)). Theoretical calculations: dark blue square (molecular dynamics (Guillot and Sator, 2007)), red curve (compression of anorthite applied to basalt, de Koker (2010)), orange curve (compression of diopside applied to basalt, Sun et al. (2011)). Data on crystalline assemblages: pink line (eclogite, $1973 \mathrm{~K}$, Aoki and Takahashi (2004)), blue line (eclogite, $1873 \mathrm{~K}$, Litasov et al. (2004)), purple squares (in situ x-ray diffraction on crystallized basalt, $2050 \mathrm{~K}$ Perrillat et al. (2006)), black squares (in situ x-ray diffraction on crystallized basalt, $\mathrm{T}=1750-2290 \mathrm{~K}$, Hirose et al. (2005)).

specific of melts unlike cold compressed glasses, for which the FSDP shift with pressure is much slower (Fig.4). However, if the glass is heated up 
to the glass transition temperature, then the pressure behavior is similar. Having a similar structure to that of melts. relaxed glasses are thus good

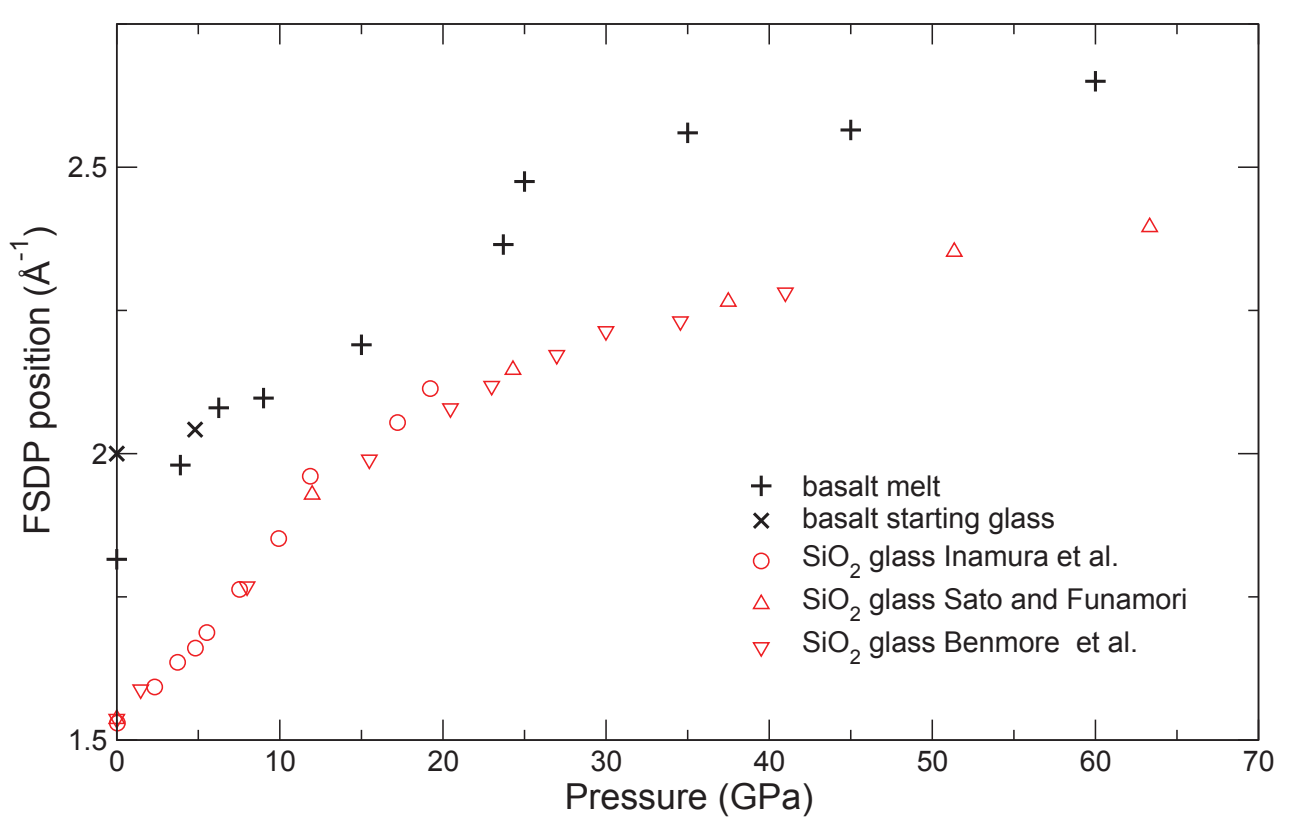

Figure 4: Tracking densification of melts structure through the evolution of the first sharp diffraction peak (FSDP). Data for basalt are from (Drewitt et al., 2013; Crépisson et al., 2014; Sanloup et al., 2013b) by order of increasing pressure, data for $\mathrm{SiO}_{2}$ glass are from (Inamura et al., 2004; Benmore et al., 2011; Sato and Funamori, 2010).

In terms of bulk modulus, this low $P$ domain is characterised by $K_{T, 0}$ values ranging between 15 and $35 \mathrm{GPa}$ (Fig.5). Good agreement is observed between x-ray absorption and sink-float experiments carried out below 10 GPa. The concentration of topological voids increases with the $\mathrm{SiO}_{2}$ content of the melt, hence the observed trend in compressibility (inverse of the bulk modulus, $K_{T}$ ), with siliceous magmas being more compressible than basic magmas as previously pointed out (Seifert et al., 2013; Wang et al., 2014).

This domain is the most interesting one not only in terms of application to present-day magmatism as $5 \mathrm{GPa}$ is near the deepest zone from which magma may rise to the surface, but also because it is the domain on which 


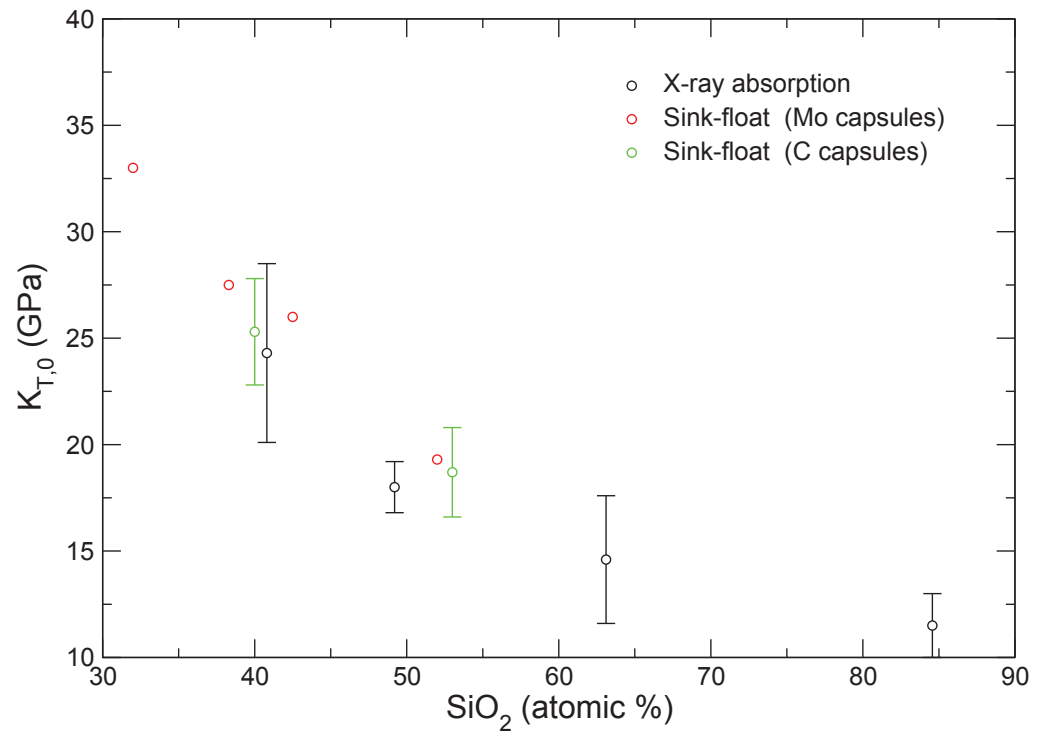

Figure 5: Isothermal bulk modulus, $K_{T, 0}$ vs $\mathrm{SiO}_{2}$ content. Only dry compositions are plotted, and data that were fitted with very high $K$ ' values (above 7 ) were discarded in order to be able to compare $K_{T, 0}$ values. Red points (sink-float): komatiite-fayalite $\left(32 \% \mathrm{SiO}_{2}\right.$ from Agee (2008)), peridotite $\left(38 \% \mathrm{SiO}_{2}\right.$ from Agee (1998)), komatiite (42.5\% $\mathrm{SiO}_{2}$ from Agee (1998)), basalt $\left(52 \% \mathrm{SiO}_{2}\right.$ from Agee (1998)). Green points (sink-float) : peridotite $\left(40.8 \% \mathrm{SiO}_{2}\right.$ from Sakamaki et al. (2010b)), basalt (53.7\% $\mathrm{SiO}_{2}$ from Ohtani and Maeda (2001)). Black points (X-ray absorption): basalt (50.6\% $\mathrm{SiO}_{2}$ from Crépisson et al. (2014)), phonolite $\left(67.9 \% \mathrm{SiO}_{2}\right.$ from Seifert et al. (2013)), andesite $\left(67.9 \% \mathrm{SiO}_{2}\right.$ from Malfait et al. (2014a)), rhyolite (84.6\% $\mathrm{SiO}_{2}$ from Malfait et al. (2014b)).

magmas are most compressible and most sensitive to the water content. The partial volume of water in silicate melts strongly diminishes at low $P$ and much less so above 5 GPa (Agee, 2008; Sakamaki et al., 2009; Malfait et al., 2014a). Hence below $5 \mathrm{GPa}$ is the domain where magmas properties change most.

\subsection{Increase of coordination number: main elements $\mathrm{Si}, \mathrm{Mg}, \mathrm{Fe}, \mathrm{Al}, \mathrm{Ca}$}

$\mathrm{Si}$ and $\mathrm{Al}$ coordination changes from 4 to 6 in glasses have been revealed respectively between $10 \mathrm{GPa}$ and $40 \mathrm{GPa}$ (Meade et al., 1992) for $\mathrm{SiO}_{2}$ using in situ x-ray diffraction, and from 5 to $15 \mathrm{GPa}$ using NMR spectroscopy on glasses synthesised at high $P$ (Yarger et al., 1995). ${ }^{27} \mathrm{Al}$ and ${ }^{29} \mathrm{Si} \mathrm{NMR}$ spectroscopy have since been applied to a variety of glasses synthesised up to 
$12 \mathrm{GPa}$ (see Lee et al. (2012) and references therein). In situ measurements on melts showed that the evolution with $P$ of silicon coordination is similar for molten basalt and silica glass (Sanloup et al., 2013b). Coordination changes thus do not seem to considerably depend on magma composition nor on the glassy vs molten state. Coordination numbers for the main cations present in compressed magmas (i.e. $\mathrm{Si}, \mathrm{Mg}, \mathrm{Fe}, \mathrm{Al}, \mathrm{Ca}$ ) have been theoretically computed, some have been measured either in the glassy or molten states. All these informations are compiled in Fig.6.

The effect of coordination change can be drastic for end-member compositions but in natural complex melts, many different $\mathrm{CN}$ increase may occur (Fe, Al, $\mathrm{Ca}, \mathrm{Mg}, \mathrm{Si}$ ), smoothing out the intermediate domains even though the strongest densification effect remains linked to $\mathrm{Si}$ as the major cation. The case of Fe deserves some more attention as it is a key element in many respects (Wilke, 2005): it can have different valence and oxidation states, its concentration varies a lot among planetary magmas, and it is the heaviest major element. Under $P$, Fe coordination change occurs at slightly lower $P$ than for Mg (Sanloup et al., 2013a), thus further increasing the density of Fe-rich magmas at depth.

When high $P$ sink-float data points $(>10 \mathrm{GPa})$ are considered, higher $K_{T, 0}$ values are obtained compared to lower $P$ data sets, with values up to $35 \mathrm{GPa}$ for molten peridotite for density measurements carried between 20 and $24 \mathrm{GPa}$ (Suzuki et al., 1995). This observed stiffening of silicate melts is consistent with the reported coordination changes and consequent atomic compaction.

\subsection{Crystal-like behavior at very high pressures}

Above $35 \mathrm{GPa}$, Si coordination change and most others are completed, leaving bond compressibility as the main compression mechanism, as in crystals. Solid-like behavior has been proposed for close-packed silicate liquids at very high pressures (Wolf et al., 2015). Magmas density and compressibility are therefore expected to be similar to or not very far from that of crystalline phases, as can be seen from the comparison between molten and crystalline basalt (Fig.3). In terms of intermediate range order, the position of the first sharp diffraction peak $q_{\max }$ (cf section 3.1), its shift with $P$ clearly decelerates above $35 \mathrm{GPa}$. The comparison of $q_{\max }^{3}$, where $q_{\max }$ is the position of the first sharp diffraction peak, with scaled density shows that in the highest $P$-regime, above $30-35 \mathrm{GPa}$, the density is proportional to $\left(q / q_{0}\right)^{3}$ for both $\mathrm{SiO}_{2}$ glass and molten basalt (Fig.7). Such behavior is typical of simple 


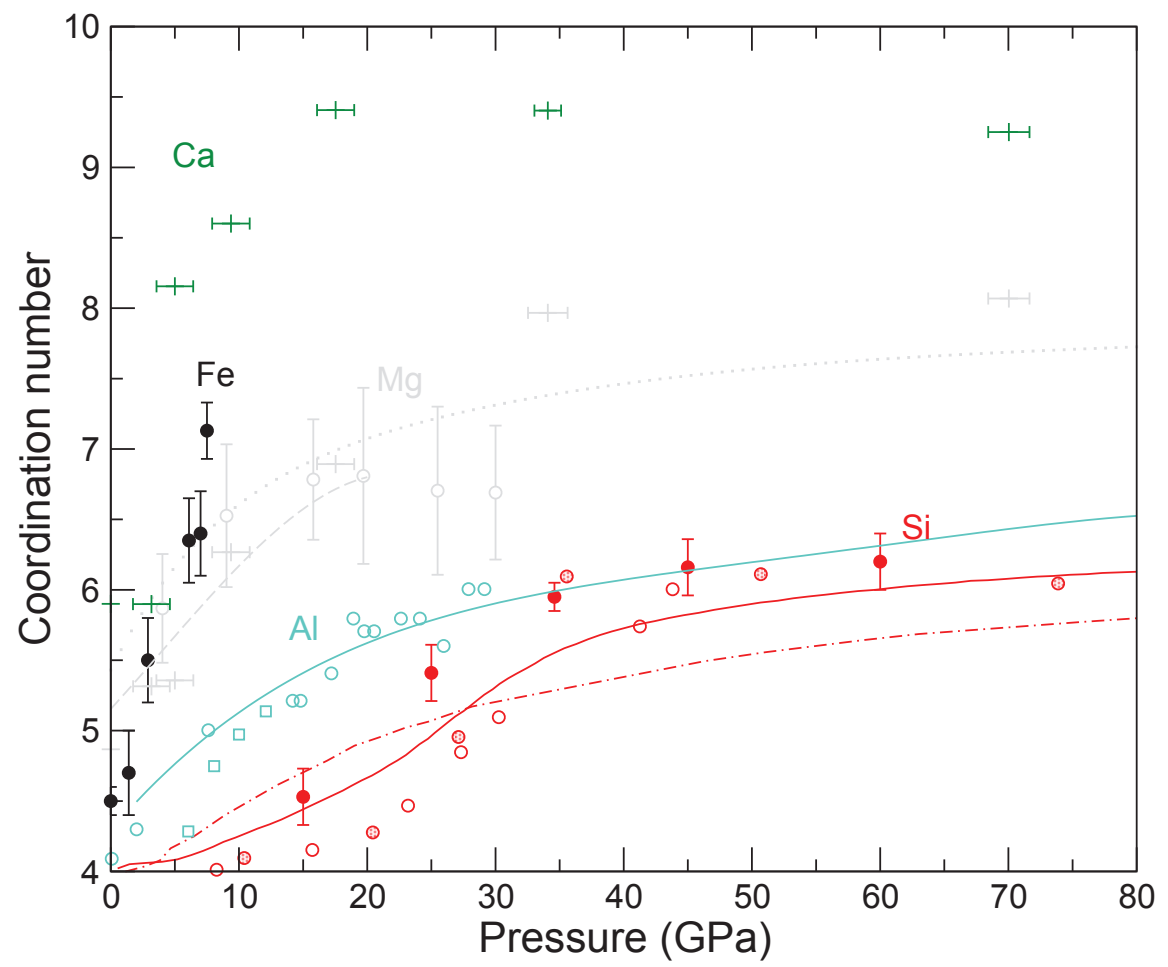

Figure 6: Increase of the X-O coordination number for the major cations in silicate melts. Experimental data (full symbols are for melts, empty symbols for glasses) are from x-ray diffraction data unless otherwise stated; black circles: Fe (Sanloup et al., 2013a), grey circles: $\mathrm{Mg}$ (Benmore et al., 2011) on $\mathrm{Mg}_{2} \mathrm{SiO}_{4}$ glass assuming CN Si increase as reported by same authors on $\mathrm{SiO}_{2}$ glass (Benmore et al., 2010), blue circles: $\mathrm{Al}$ in anorthite glass (Drewitt et al., 2015), blue squares: Al in quenched sodium-aluminium silicate glasses from NMR (Yarger et al., 1995), empty red circles: $\mathrm{Si}$ in $\mathrm{SiO}_{2}$ glass (Benmore et al., 2010), dotted red circles: $\mathrm{Si}$ in $\mathrm{SiO}_{2}$ glass (Sato and Funamori, 2008), full circles: $\mathrm{Si}$ in molten basalt (Sanloup et al., 2013b). Theoretical calculations (plus signs): green for Ca in diopside melt (Sun et al., 2011), grey for Mg in diopside melt (Sun et al., 2011). Theoretical calculations (lines): grey dotted line for $\mathrm{Mg}$ in forsterite melt (de Koker et al., 2008), grey dashed line for $\mathrm{Mg}$ in molten basalt (Guillot and Sator, 2007), blue line for $\mathrm{Al}$ in anorthite melt (de Koker, 2010), red full line for $\mathrm{Si}$ in $\mathrm{SiO}_{2}$ melt Karki et al. (2007), red dashed line for Si in anorthite melt (de Koker, 2010).

liquids for which $q_{\max }=k \rho^{3}$ (Hansen and Schiff, 1973). The consequence of that is that the compressibility of magmas above $35 \mathrm{GPa}$ can be simply deduced from the shift of the FSDP on $S(q)$. 
The convergence between the density of crystalline and molten phases for basalt at lower mantle $P$ illustrated on Fig.3 has also been predicted for per-

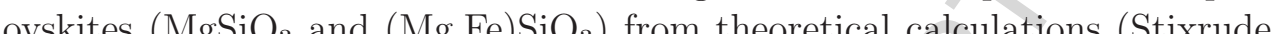
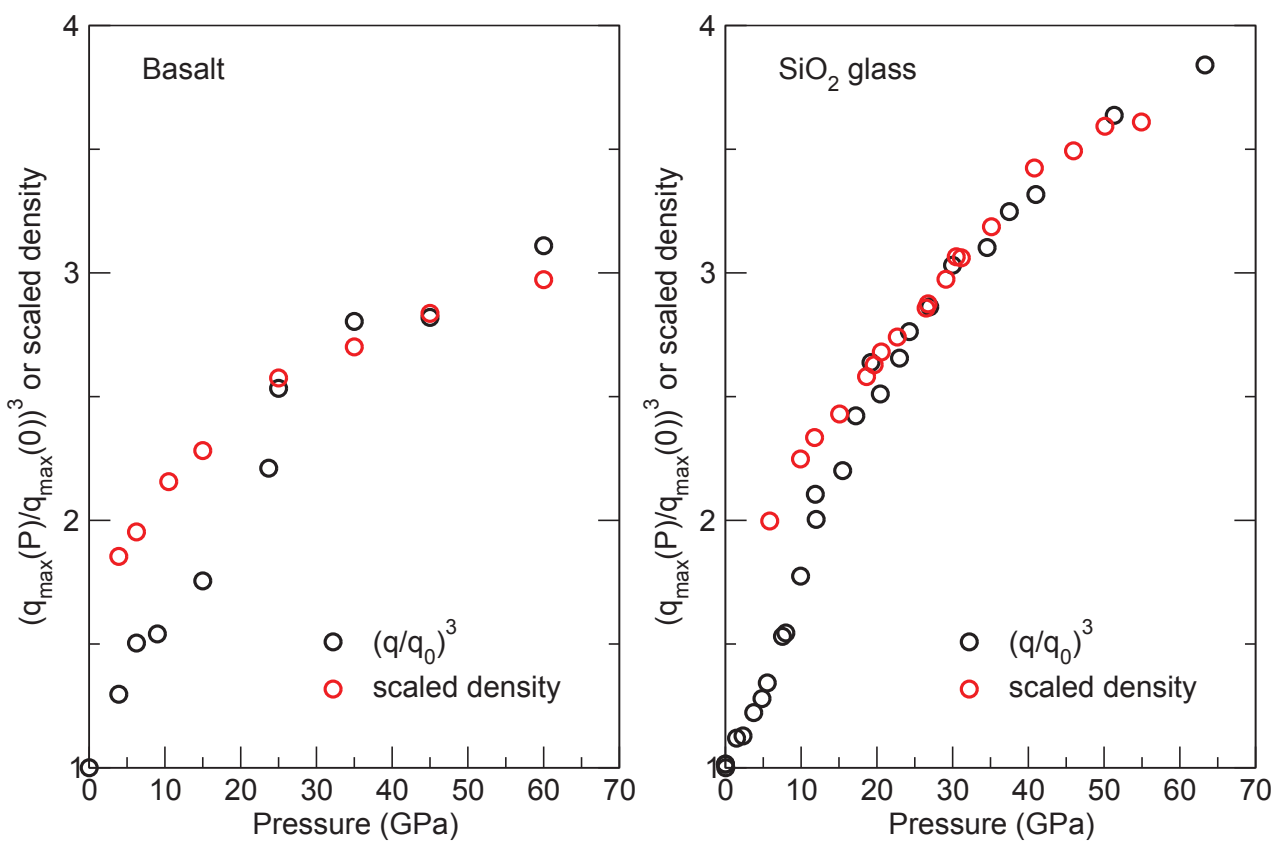

Figure 7: Evolution of the position of the first sharp diffraction peak $\left(q_{\max }\right)$ with $P$ compared to that of density scaled down to match the evolution of $q_{\max }(P) / q_{\max }(0)$ at the highest $P$. For basalt, $q_{\max }$ values have been taken from Sanloup et al. (2013b), for $\mathrm{SiO}_{2}$ glass, they are from Sato and Funamori (2010) and Inamura et al. (2004).

\section{How the densification of magmas affect their geochemical and geophysical properties}

\subsection{Control on element partitioning}

A lot of efforts have been devoted to measuring partitioning of siderophile elements between metallic and silicate melts as a function of $P, \mathrm{fO}_{2}$ and melts compositions. The resulting database is precious to help us establishing a link between element partitioning and melt compression mechanisms. 
A compilation of nickel metal-silicate partition coefficient, $\mathrm{D}^{N i}$, evidences three different $P$ domains: from ambient to circa $5 \mathrm{GPa}$, from circa 5 to circa $30 \mathrm{GPa}$, and above that (Fig. 8). The first change in P-dependency is also observed for Co (Kegler et al., 2008) and W (Cottrell et al., 2009). This change has been first interpreted as resulting from gradual coordination changes of $\mathrm{Ni}$ and $\mathrm{Co}$ in the silicate melts (Kegler et al., 2008), and later related to a compressibility change of molten Fe and Fe-C alloys (Sanloup et al., 2011). The above discussion on the compression mechanisms in magmas brings another light on the matter. Both changes in the $P$-dependency of nickel partitioning coefficient indeed coincide with the major changes of compression mechanism and consequent stiffening of silicate melts. A decrease in magma compressibility would reduce the elastic strain associated with element substitution in the liquid metal host (Blundy and Wood, 1994), as the increase of molten $\mathrm{Fe}-\mathrm{C}$ alloys compressibility reported above $5 \mathrm{GPa}$ would, both causes resulting in a slower decrease of $\mathrm{D}^{N i}$ with $P$ (cf Fig. 8).

Another consequence of densification related to cations coordination gradual increase in magmas is potential isotopic fractionation between co-existing crystals and melts. In two co-existing equilibrated phases, the phase with the highest $\mathrm{X}-\mathrm{O}$ coordination number and/or longest $\mathrm{X}-\mathrm{O}$ bond is enriched in light isotopes (Urey, 1947). Silicon isotopic fractionation between minerals and melts has been measured between 1 and $7 \mathrm{GPa}$, and no $P$ effect was observed (Shahar et al., 2011). However, the largest Si isotope fractionation occurs between phases with different coordination number of $\mathrm{Si}$, and below $7 \mathrm{GPa}$ Si coordination number is identical in the minerals and in the melt. In contrast, perovskite is expected to be enriched in light Si isotopes with respect to a melt at the top of the lower mantle, and less and less so as depth increases and Si coordination number reaches 6 in the melt. Crystallization of the magma ocean could have thus resulted in fractionation of $\mathrm{Si}$ isotopes. Similarly, Si isotopic fractionation between molten silicates and molten iron is expected to decrease with increasing $P$ (Huang et al., 2014), thus lessening the imprint of core formation on terrestrial rocks Si isotopic signature.

\subsection{Density traps}

Density inversions between melts and coexisting minerals have long been predicted to occur during the magma ocean era. But density traps are likely at stake in the current-day Earth. The presence of carbonatitic melts has been proposed at the oceanic lithosphere-asthenosphere boundary on the 


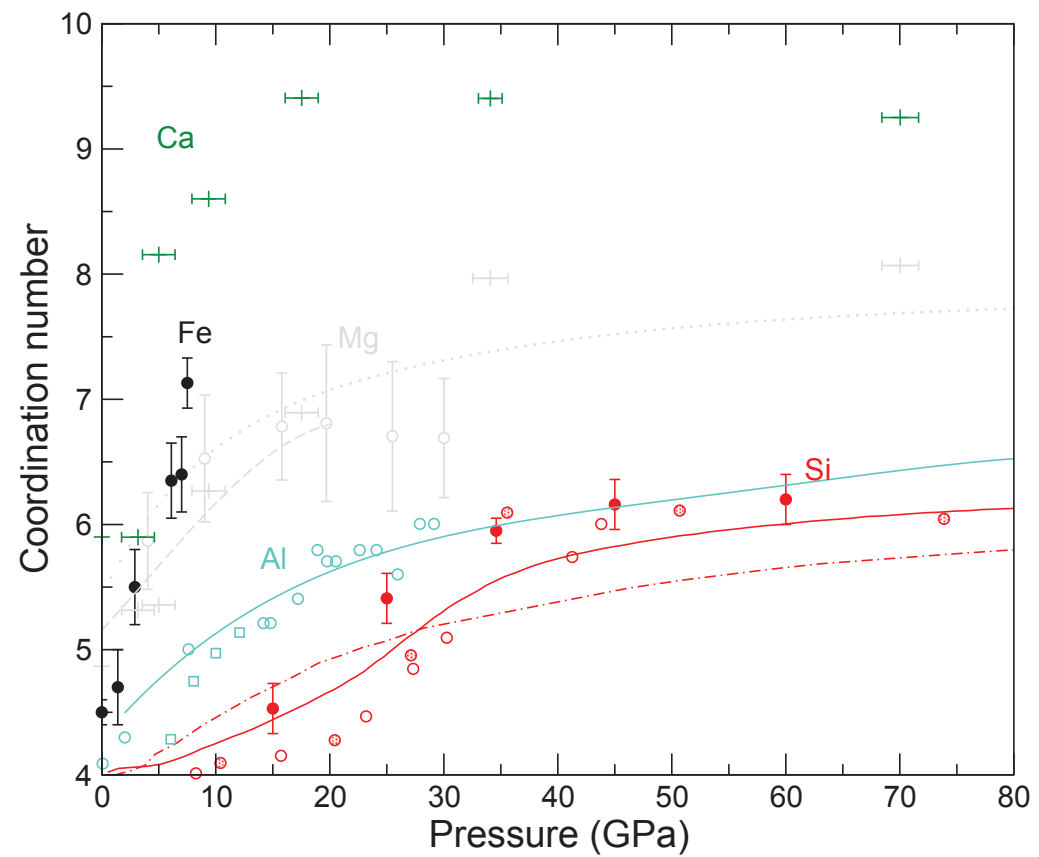

Figure 8: Pressure evolution of the metal-silicate partition coefficient for nickel, $\mathrm{D}^{N i}$ (adapted from Sanloup et al. (2013b)). Data are from: circles (Li and Agee, 1996), diamonds (Thibault and Walter, 1995), upper triangles (O'Neill et al., 1998), right triangles (Ohtani and Yurimoto, 1996), squares (Tschauner et al., 1999), down triangles (Siebert et al., 2012). Black lines are guide for the eyes.

basis of melting relationships (Dasgupta et al., 2013), and electrical conductivity measurements (Gaillard et al., 2008). Ponding of basaltic melts is nonetheless favored by other physical considerations. The density/viscosity ratio is highest at 150-180 km depth but greatly reduces at shallower depth which might impede melt mobility upwards (Sakamaki et al., 2013). Alkalirich basalts could be produced and trapped at the continental lithosphereasthenosphere boundary since mid-Archean times, being neutrally buoyant at these conditions (Crépisson et al., 2014). For all these cases, the presence of melts below lithospheric plates provides an important lubrication mechanism. An issue that remains to be solved is which melts are trapped above the $410 \mathrm{~km}$ and $660 \mathrm{~km}$ discontinuities (Tauzin et al., 2010; Schmandt et al., $2014)$, likely in relation with dehydration of either ascending $(410 \mathrm{~km})$ or 
descending $(660 \mathrm{~km})$ mantle out of the water-rich mantle transition zone. Archean melts have been postulated to be gravitationally stable at $410 \mathrm{~km}$ (Lee, 2006), but the nature of the current-day melts remains to be elucidated. These are geochemically important magmas as they could have a filtering role for incompatible elements (Bercovici and Karato, 2003). For non-terrestrial bodies, density traps have been reported for Ti-rich basalts at the bottom of the lunar mantle (Van Kan Parker et al., 2012) consistently with seismic indications of partial melt (Weber et al., 2011). The compressibility contrast between melt and crystals being largest at low pressures, density inversions are less expected to occur at the extreme conditions relevant of the terrestrial lower mantle unless significant compositional differences occur. An Fe-rich magma for instance may still be negatively buoyant at the base of the mantle, and could be produced either by melting of subducted oceanic crust or by enhanced enrichment of Fe in partial melts above the Fe spin transition circa 70 GPa (Nomura et al., 2011), although such Fe enrichment is a matter of debate (Andrault et al., 2012). If ULVZ do contain melt, then their higher density as probed by seismology implies that they must have a different composition from that of the surrounding crystalline mantle.

\subsection{Implications for the magma ocean era}

Arguments for a fully molten mantle are: 1) the remnants of the magma ocean atop the core in ULVZs (Williams and Garnero, 1996), 2) the much steeper adiabatic profiles of silicate liquids at extreme pressures than the liquidus (Stixrude et al., 2009; Asimow and Ahrens, 2010; Wolf et al., 2015), 3) the amount of energy released upon impact (Tonks and Melosh, 1993) that is sufficient to melt the whole mantle. Arguments for a partial magma ocean are essentially the depth of equilibrium between molten silicates and molten iron estimated from siderophile elements partitioning at depth, that range between 40 and $60 \mathrm{GPa}$ (Li and Agee, 2001; Bouhifd and Jephcoat, 2011; Siebert et al., 2013), and the incomplete homogeneization of the mantle for noble gas isotopes (Tucker and Mukhopadhyay, 2014). However, this estimated depth might represent some sort of average as core formation likely results from more than one magma ocean stage and from more than one segregation mechanisms, not all occurring at equilibrium (Rubie et al., 2011). Besides, the flattening of siderophile elements partitioning above $35 \mathrm{GPa}$ makes estimations of equilibrium $P$ prone to large error bars (Sanloup et al., 2013b). 


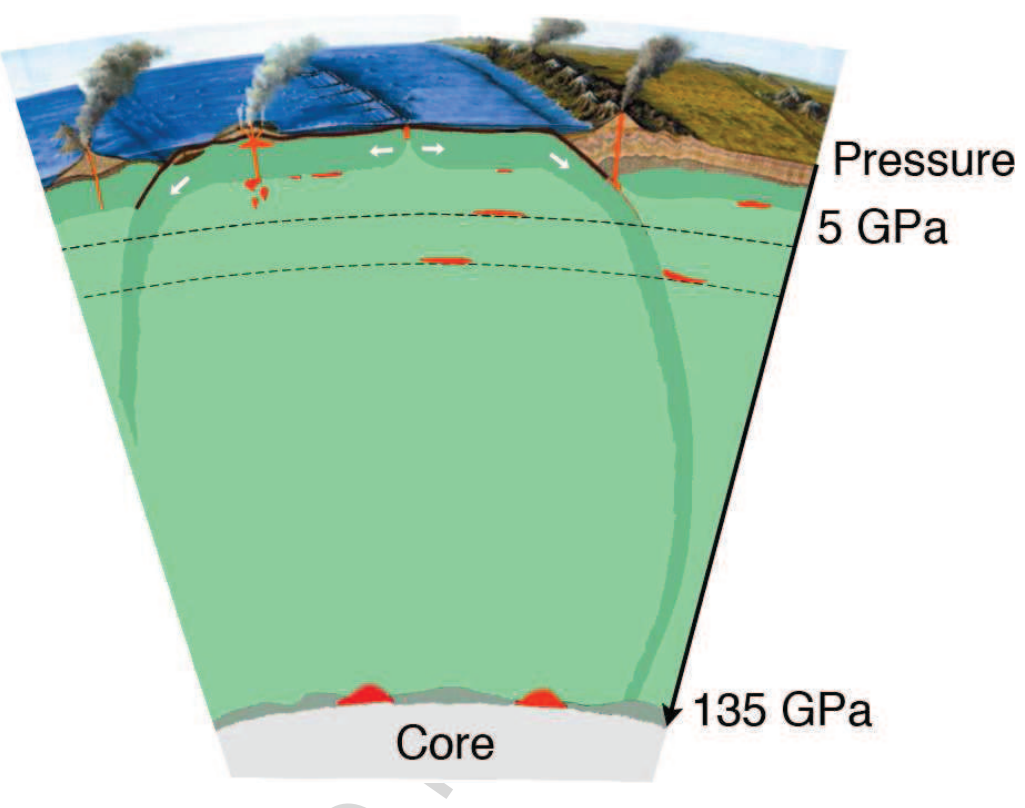

Figure 9: Where are magmas (orange pockets) in the mantle?

If crystallization proceeds from the bottom-up, a whole magma ocean will tend to lessen any differentiation imprint, whether geochemical (elemental and isotopic fractionation, cf section 4.1) or geophysical (segregation of liquid vs crystals). In contrast, if crystallization proceeds from the top of the lower mantle, i.e. where Si coordination number and density contrasts between the magma and crystals are the largest, then fractionation will be enhanced. Crystallization from intermediate-mantle depths has been proposed by Labrosse et al. (2007) on the basis of cooling models that predict solidification of a single magma ocean within less than 1 My (Solomatov, 2000; Labrosse et al., 2007; Elkins-Tanton, 2008), i.e. way too fast to be reconciled with geochemical formation times for the core and the atmosphere (few tens of My). From density considerations, a layer of crystals could be gravitationally stable at the top of the lower mantle (Sanloup et al., 2013b), but this remains to be confirmed by the comparison of reliable adiabats and liquidus curves for the appropriate magma ocean composition. 


\section{Conclusions and future directions}

The last ten years have witnessed large progresses in our knowledge of magmas density at depth. In terms of compositional space, all major natural silicate melts have been investigated (from rhyolite to komatiite melts). In terms of $P$, fine meshing is now available and lower mantle conditions can be reached in dynamic and static conditions. Only a few melts have been studied at lower mantle conditions, with more extensive work carried out on basalt, and investigations remain to be done for magma ocean analogues. The existing density and structural data on molten basalt and silica glass down to lower mantle conditions reveal three main $P$-regimes controlled by different compression mechanisms that are successively voids compaction $(<5$ $\mathrm{GPa}$ ), cations coordination increase, and bond compressibility (>35 GPa). Magmas are much more compressible than their crystalline counterparts at low $P$, leading to the possibility to trap magmas at depth in some geodynamical contexts. Magmas become stiffer with increased $P$, eventually reaching crystal-like compressibility values. Clear links can be established between the $P$-dependence of nickel metal/silicate partitioning and stiffening of silicate melts in relation with change of compression mechanisms. It is essential that equivalent databases for partitioning of lithophile elements between crystals and melts be established from crust to core-mantle boundary conditions, in order to test if partitioning should similarly lessen at extreme pressures. Our understanding of deep-seated magmas and of the magma ocean era would be strongly enhanced from future progresses in this direction.

Another direction to follow is that of viscosity measurements at all mantle conditions. Viscosity has now been measured for a wide range of magma compositions but only barely to the point at which it is supposed to take off by a few orders of magnitude from theoretical calculations (Karki and Strixrude, 2010), and the highest $P$ points (13 GPa) on depolymerized magmas only show a slight increase in viscosity (Reid et al., 2003; Liebske et al., 2005). Developing methods to measure the viscosity at lower mantle conditions is an area where experimental efforts should go.

\section{Acknowledgements:}

The research leading to these results has received funding from the European Community's Seventh Framework Programme (FP7/2007-2013) under grant agreements no. 312284 and 259649 (European Research Council starting grant). 
Agee, C. B., 1998. Crystal-liquid density inversions in terrestrial and lunar magmas. Phys. Earth Planet. Int. 107, 63-74.

Agee, C. B., 2008. Static compression of hydrous silicate melt and the effect of water on planetary differentiation. Earth Planet. Sci. Lett. 265, 641-654.

Ai, Y., Lange, R. A., 2008. New acoustic velocity measurements on CaO$\mathrm{MgO}-\mathrm{Al}_{2} \mathrm{O}_{3}-\mathrm{SiO}_{2}$ liquids: Reevaluation of the volume and compressibility of $\mathrm{CaMgSi}_{2} \mathrm{O}_{6}-\mathrm{CaAl}_{2} \mathrm{Si}_{2} \mathrm{O}_{8}$ liquids to 25 gpa. J. Geophys. Res. 113, B04203.

Andrault, D., Petitgirard, S., Nigro, G. L., Devidal, J. L., Veronesi, G., Gabarino, G., Mezouar, M., 2012. Solidliquid iron partitioning in Earths deep mantle. Nature 487, 354-357.

Aoki, I., Takahashi, E., 2004. Density of MORB eclogite in the upper mantle. Phys. Earth Planet. Int. 143, 129-143.

Asimow, P. D., Ahrens, T., 2010. Shock compression of liquid silicates up to 125 GPa: the anorthite-diopside join. J. Geophys. Res. 115, B10209.

Benmore, C. J., Soignard, E., Amin, S. A., Guthrie, M., Shastri, S. D., Lee, P. L., Yarger, J. L., 2010. Structural and topological changes in silica glass at pressure. Phys. Rev. B 81, 054105.

Benmore, C. J., Soignard, E., Guthrie, M., Amin, S. A., McKiernan, K., Wilding, M. C., Yarger, J. L., 2011. High pressure x-ray diffraction measurements on $\mathrm{Mg}_{2} \mathrm{SiO}_{4}$ glass. J. Non Cryst. Sol. 357, 2632-2636.

Bercovici, D., Karato, S.-I., 2003. Whole-mantle convection and the transition-zone water filter. Nature 425, 39-44.

Blundy, J., Wood, B. J., 1994. Prediction of crystal-melt partition coefficients from elastic moduli. Nature 372, 452-454.

Bouhifd, M. A., Jephcoat, A., 2011. Convergence of Ni and Co metal silicate partition coefficients in the deep magma-ocean and coupled silicon-oxygen solubility in iron melts at high pressures. Earth Planet. Sci. Lett. 307, 341-348.

Carlson, R. W., Garnero, E., Harrison, T. M., Li, J., Manga, M., McDonough, W. F., Mukhopadhyay, S., Romanowicz, B., Rubie, D., 
Williams, Q., Zhong, S., 2014. How did Early earth become our modern world? Annu. Rev. Earth Planet. Sci. 42, 151-178.

Cottrell, E., Walter, M. J., Walker, D., 2009. Metal-silicate partitioning of tungsten at high pressure and temperature: Implications for equilibrium core formation in Earth. Earth Planet. Sci. Lett. 281, 275-287.

Crépisson, C., Morard, G., Bureau, H., Prouteau, G., Morizet, Y., Petitgirard, S., Sanloup, C., 2014. Magmas trapped at depth and the continental lithosphere-asthenosphere boundary. Earth Planet. Sci. Lett. 393, 105-112.

Dasgupta, R., Mallik, A., Tsuno, K., Withers, A. C., Hirth, G., Hirschmann, M. M., 2013. Carbon-dioxide-rich silicate melt in the Earth's upper mantle. Nature 493, 211-216.

de Koker, N. P., 2010. Structure, thermodynamics, and diffusion in caal $\mathrm{Si}_{2} \mathrm{O}_{8}$ liquid from first-principles molecular dynamics. Geochim. Cosmochim. Acta 74, 5657-5671.

de Koker, N. P., Stixrude, L., Karki, B. B., 2008. Thermodynamics, structure, dynamics, and freezing of $\mathrm{Mg}_{2} \mathrm{SiO}_{4}$ liquid at high pressure. Geochim. Cosmochim. Acta 72, 1427-1441.

Drewitt, J. W. E., Jahn, S., Sanloup, C., de Grouchy, C., Garbarino, G., Hennet, L., 2015. Development of chemical and topological structure in aluminosilicate liquids and glasses at high pressure. J. Phys.: Cond. Matt. $27,105103$.

Drewitt, J. W. E., Sanloup, C., Bytchkov, A., Brassamin, S., Hennet, L., 2013. Structure of $\left(\mathrm{Fe}_{x} \mathrm{Ca}_{1-x} \mathrm{O}\right)_{y}\left(\mathrm{SiO}_{2}\right)_{1-y}$ liquids and glasses from highenergy $\mathrm{x}$-ray diffraction: Implications for the structure of natural basaltic magmas. Phys. Rev. B 87, 224201.

Egelstaff, P. A., 1994. An Introduction to the Liquid State. Oxford University Press, Oxford.

Eggert, J. H., Weck, G., Loubeyre, P., Mezouar, M., 2002. Quantitative structure factor and density measurements of high-pressure in diamond anvil cells by x-ray diffraction: Argon and water. Phys. Rev. B 65, 174105. 
Elkins-Tanton, L. T., 2008. Linked magma ocean solidification and atmospheric growth for Earth and Mars. Earth Planet. Sci. Lett. 271, 181-191.

Elkins-Tanton, L. T., 2012. Magma oceans in the inner solar system. Annu. Rev. Earth Planet. Sci. 40, 113-139.

Fujii, T., 1978. Viscosity, density and ascending velocity of magma. Bull. Volcanol. Soc. Japan (2nd series) 23, 117-130.

Gaillard, F., Malki, M., Iacono-Marziano, G., Pichavant, M., Scaillet, B., 2008. Carbonatite melts and electrical conductivity in the asthenosphere. Science 322, 1363-1365.

Ghiorso, M. S., 2004. An equation of state for silicate melts. IV Calibration of a multicomponent mixing model to $40 \mathrm{GPa}$. Am. J. Sci. 304, 811-838.

Guillot, B., Sator, N., 2007. A computer simulation study of natural silicate melts. Part II: High pressure properties. Geochim. Cosmochim. Acta 71, 4538-4556.

Hansen, J.-P., Schiff, D., 1973. Influence of interatomic repulsion on structure of liquids at melting. Mol. Phys. 25, 1281-1291.

Harper, C. L., 1996. Evidence for ${ }^{92 g} \mathrm{Nb}$ in the early solar system and evaluation of a new $p$-process cosmochronometer from ${ }^{92 g} \mathrm{Nb} /{ }^{92} \mathrm{Mo}$. ApJ 466, 437-456.

Hirose, K., Takafuji, N., Sata, N., Ohishi, Y., 2005. Phase transition and density of subducted MORB crust in the lower mantle. Earth Planet. Sci. Lett. 237, 239-251.

Huang, F., Wu, Z., Huang, S., Wu, F., 2014. First-principles calculations of equilibrium silicon isotope fractionation among mantle minerals. Geochim. Cosmochim. Acta 140, 509-520.

Inamura, Y., Katayama, Y., Utsumi, W., Funakoshi, K.-I., 2004. Transformations in the intermediate-range structure of $\mathrm{SiO}_{2}$ glass under high pressure and temperature. Phys. Rev. Lett. 93, 015501.

Kaplow, R., Strong, S. L., Averbach, B. L., 1965. Radial density functions for liquid mercury and lead. Phys. Rev. 138, A1336. 
Karki, B. B., Bhattarai, D., Strixrude, L., 2007. First-principles simulations of liquid silica: Structural and dynamical behavior at high pressure. Phys. Rev. B 76, 104205.

Karki, B. B., Strixrude, L., 2010. Viscosity of $\mathrm{MgSiO}_{3}$ at Earth's manle conditions: implications for an early magma ocean. Science 328, 740-742.

Katayama, Y., Inamura, Y., Mizutani, T., Yamakata, M., Utsumi, W., Shimomura, O., 2004. Macroscopic separation of dense fluid phase and liquid phase of phosphorus. Science 306, 848-851.

Katayama, Y., Tsuji, K., Kanda, H., Nosaka, H., Yaoita, K., Kikegawa, T., Shimomura, O., 1996. Density of liquid tellurium under pressure. J. Non-Cryst. Solids 205, 451-454.

Katayama, Y., Tsuji, K., Shimomura, O., Kikegawa, T., Mezouar, M., Martinez-Garcia, D., Besson, J.-M., Hasermann, D., Hanfland, M., 1998. Density measurements of liquid under high pressure and high temperature. J. Synchrotron Radiation 5, 1023-1025.

Kegler, P., Holzheid, A., Frost, D. J., Rubie, D. C., Dohmen, R., Palme, H., 2008. New Ni and Co metal-silicate partitioning data and their relevance for an early terrestrial magma ocean. Earth Planet. Sci. Lett. 268, 28-40.

Kohara, S., Akola, J., Morita, H., Suzuya, K., Weber, J. K. R., Wilding, M. C., Benmore, C. J., 2011. Relationship between topological order and glass forming ability in densely packed enstatite and forsterite composition glasses. P. Natl. Acad. Sci. 108, 14780-14785.

Kono, Y., Park, C., Kenney-Benson, C., Shen, G., Wang, Y., 2014. Toward comprehensive studies of liquids at high pressures and high temperatures: Combined structure, elastic wave velocity, and viscosity measurements in the Paris-Edinburgh cell. Phys. Earth Planet. Int. 228, 269-280.

Labrosse, S., Hernlund, J. W., Coltice, N., 2007. A crystallizing dense magma ocean at the base of the Earth's mantle. Nature 450, 866-869.

Lange, R. A., Carmichael, I. S. E., 1987. Densities of $\mathrm{Na}_{2} \mathrm{O}-\mathrm{K}_{2} \mathrm{O}-\mathrm{CaO}-\mathrm{MgO}-$ FeO- $\mathrm{Fe}_{2} \mathrm{O}_{3}-\mathrm{Al}_{2} \mathrm{O}_{3}-\mathrm{TiO}_{2}-\mathrm{SiO}_{2}$ liquids: New measurements and derived partial molar properties. Geochim. Cosmochim. Acta 51, 2931-2946. 
Lee, C.-T. A., 2006. Geochemical/petrologic constraints on the origin of cratonic mantle. In: Benn, K and Mareschal, J. C and Condie, K. C (Ed.), Archean geodynamics and environments. Vol. 164 of Geophysical Monograph Series. pp. 89-114.

Lee, C.-T. A., Luffi, P., Plank, T., Dalton, H., Leeman, W. P., 2009. Constraints on the depths and temperatures of basaltic magma generation on Earth and other terrestrial planets using new thermobarometers for mafic magmas. Earth Planet. Sci. Lett. 279, 20-33.

Lee, S. K., Yi, Y. S., Cody, G. D., Mibe, K., Fei, Y., Mysen, B. O., 2012. Effect of network polymerization on the pressure-induced structural changes in sodium aluminosilicate glasses and melts: ${ }^{27} \mathrm{al}$ and ${ }^{17} \mathrm{O}$ solid-state NMR study. J. Phys. Chem. C 116, 21832191.

Li, J., Agee, C. B., 1996. Geochemistry of mantle-core differentiation at high pressure. Nature 381, 686-689.

Li, J., Agee, C. B., 2001. The effect of pressure, temperature, oxygen fugacity and composition on partitioning of nickel and cobalt between liquid FeNi-S alloy and liquid silicate: Implications for the Earth's core formation. Geochim. Cosmochim. Acta 65, 1821-1832.

Liebske, C., Schmickler, B., Terasaki, H., Poe, B., Suzuki, A., Funakoshi, K., Ando, R., Rubie, D., 2005. Viscosity of peridotite liquid up to 13 GPa: implications for magma ocean viscosities. Earth Planet. Sci. Lett. 240, 589-604.

Litasov, K., Ohtani, E., Suzuki, A., Kawazoe, T., Funakoshi, K., 2004. Absence of density crossover between basalt and peridotite in the cold slabs passing through $660 \mathrm{~km}$ discontinuity. Geophys. Res. Lett. 31, L24607.

Malfait, W. J., Seifert, R., Petitgirard, S., Mezouar, M., Sanchez-Valle, C., 2014a. The density of andesitic melts and the compressibility of dissolved water in silicate melts at crustal and upper mantle conditions. Earth. Planet. Sci. Lett. 393, 31-38.

Malfait, W. J., Seifert, R., Petitgirard, S., Perrillat, J.-P., Mezouar, M., Ota, T., Nakamura, E., Lerch, P., Sanchez-Valle, C., 2014b. Supervolcano eruptions driven by melt buoyancy in large silicic magma chambers. Nat. Geoscience 7, 122-125. 
Malfait, W. J., Seifert, R., Sanchez-Valle, C., 2014c. Densified glasses as structural proxies for high-pressure melts: Configurational compressibility of silicate melts retained in quenched and decompressed glasses. Am. Mineral. 99, 2142-2145.

Meade, C., Hemley, R. J., Mao, H. K., 1992. High-pressure x-ray diffraction of $\mathrm{SiO}_{2}$ glass. Phys. Rev. Lett. 69, 1387-1390.

Mezouar, M., Faure, P., Crichton, W., Rambert, N., Sitaud, B., Bauchau, S., Blattmann, G., 2002. Multichannel collimator for structural investigation of liquids and amorphous materials at high pressures and temperatures. Rev. Sci. Instrum. 73, 3570-3574.

Nomura, R., Ozawa, H., Tateno, S., Hirose, K., Hernlund, J., Muto, S., Ishii, H., Hiraoka, N., 2011. Spin crossover and iron-rich silicate melt in the Earths deep mantle. Nature 473, 199-203.

Ohtani, E., 2009. Melting relationships and the equation of state of magmas at high pressure: Application to geodynamics. Chem. Geol. 265, 279-288.

Ohtani, E., Maeda, M., 2001. Density of basaltic melt at high pressure and stability of the melt at the base of the lower mantle. Earth Planet. Sci. Lett. 193, 69-75.

Ohtani, E., Yurimoto, H., 1996. Element partitioning between metallic liquid, magnesiowustite, and silicate liquid at $20 \mathrm{GPa}$ and $2500^{\circ} \mathrm{c}$ : A secondary ion mass spectrometric study. Geophys. Res. Lett. 23, 1993-1996.

O’Neill, H. S. C., Canil, D., Rubie, D. C., 1998. Oxide-metal equilibria to $2500{ }^{\circ} \mathrm{C}$ and $25 \mathrm{GPa}$ : implications for core formation and the light component in the Earth's core. J. Geophys. Res. 103, 12,239-12,260.

Perrillat, J.-P., Ricolleau, A., Daniel, I., Fiquet, G., Mezouar, M., Guignot, N., Cardon, H., 2006. Phase transformations of subducted basaltic crust in the upmost lower mantle.

Reid, J., Suzuki, A., Funakoshi, K., Terasaki, H., Poe, B., Rubie, D., Ohtani, E., 2003. The viscosity of $\mathrm{CaMgSi}_{2} \mathrm{O}_{6}$ liquid at pressures up to $13 \mathrm{GPa}$. Phys. Earth Planet. Int. 139, 45-54. 
Rigden, S. M., Ahrens, T. J., Stolper, E. M., 1984. Densities of liquid silicate at high pressures. Science 226, 1071-1074.

Rivers, M. L., Carmichael, I. S. E., 1987. Ultrasonic studies of silicate melts. J. Geophys. Res. 92, 9247-9270.

Rowan, L., 1993. I. Equation of state of molten mid-ocean ridge basalt. II. Structure of Kilauea volcano. Ph.D. thesis, California Institute of Technology.

Rubie, D., D. J. Frost, U. M., Asahara, Y., Nimmo, F., Tsuno, K., Kegler, P., Holzheid, A., Palme, H., 2011. Heterogeneous accretion, composition and core-mantle differentiation of the Earth. Earth Planet. Sci. Lett. 301, $31-42$.

Sakamaki, T., Ohtani, E., Urakawa, S., Katayama, Y., 2010a. Density of dry peridotite magma at high pressure using an x-ray absorption method. Am. Mineral. 95, 144-147.

Sakamaki, T., Ohtani, E., Urakawa, S., Suzuki, A., Katayama, Y., 2009. Measurement of hydrous peridotite magma density at high pressure using the x-ray absorption method. Earth Planet. Sci. Lett. 287, 293-297.

Sakamaki, T., Ohtani, E., Urakawa, S., Suzuki, A., Katayama, Y., Zhao, D., 2010b. Density of high-Ti basalt magma at high pressure and origin of heterogeneities in the lunar mantle. Earth Planet. Sci. Lett. 299, 285-289.

Sakamaki, T., Ohtani, E., Urakawa, S., Terasaki, H., Katayama, Y., 2011. Density of carbonated peridotite magma at high pressure using an X-ray absorption method. Am. Mineral. 96, 553-557.

Sakamaki, T., Suzuki, A., Ohtani, E., 2006. Stability of hydrous melt at the base of the Earth's upper mantle. Nature 439, 192-194.

Sakamaki, T., Suzuki, A., Terasaki, H., Urakawa, S., Katayama, Y., Funakoshi, K., Hernlund, J., Ballmer, M., 2013. Ponded melt at the boundary between the lithosphere and asthenosphere. Nature Geo. 6, 1041-1044.

Salmon, P. S., 1994. Real space manifestation of the first sharp diffraction peak in the structure factor of liquid and glassy materials. Proc. Math. Phys. Sci. 445, 351-365. 
Sanloup, C., Drewitt, J. W. E., Crépisson, C., Kono, Y., Park, C., McCammon, C., Hennet, L., Brassamin, S., Bytchkov, A., 2013a. Structure and density of molten fayalite at high pressure. Geochim. Cosmochim. Acta 118, 118-128.

Sanloup, C., Drewitt, J. W. E., Konôpková, Z., Dalladay-Simpson, P., Morton, D. M., Rai, N., van Westrenen, W., Morgenroth, W., 2013b. Structural change in molten basalt at deep mantle conditions. Nature 503, 104-107.

Sanloup, C., Fiquet, G., Gregoryanz, E., Morard, G., Mezouar, M., 2004. Effect of Si on liquid Fe compressibility: Implications for sound velocity in core materials. Geophys. Res. Lett. 31, L07604.

Sanloup, C., Gregoryanz, E., Degtyareva, O., Hanfland, M., 2008. Structural transition in compressed amorphous sulfur. Phys. Rev. Lett. 100, 075701.

Sanloup, C., Guyot, F., Gillet, P., Fiquet, G., Mezouar, M., Martinez, I., 2000. Density measurements of liquid Fe-S alloys at high-pressure. Geophys. Res. Lett. 27, 811-814.

Sanloup, C., van Westrenen, W., Dasgupta, R., Maynard-Casely, H. E., Perrillat, J.-P., 2011. Compressibility change in iron-rich melt and implications for core formation models. Earth Planet. Sci. Lett. 306, 118-122.

Sato, T., Funamori, N., 2008. Sixfold-coordinated amorphous polymorph of $\mathrm{SiO}_{2}$ under high pressure. Phys. Rev. Lett. 101, 255502.

Sato, T., Funamori, N., 2010. High-pressure structural transformation of $\mathrm{SiO}_{2}$ glass up to 100 GPa. Phys. Rev. B 82, 184102.

Schmandt, B., Jacobsen, S. D., Becker, T. W., Liu, Z. K., Dueker, K. G., 2014. Dehydration melting at the top of the lower mantle. Science 344, 1265-1268.

Schmerr, N., 2012. The Gutenberg discontinuity: Melt at the lithosphereasthenosphere boundary. Science 335, 1480-1483.

Schmidt, M. W., S.Poli, 2014. Devolatilization During Subduction. Elsevier, The Netherlands, Ch. 4, pp. 669-701. 
Seifert, R., Malfait, W. J., Sanchez-Valle, C., 2013. Density of phonolitic magmas and time scales of crystal fractionation in magma chambers. Earth Planet. Sci. Lett. 381, 12-20.

Shahar, A., Hillgren, V. J., Young, E. D., Fei, Y., Macris, C. A., Deng, L., 2011. High-temperature Si isotope fractionation between iron metal and silicate. Geochim. Cosmochim. Acta 75, 7688-7697.

Shen, G., Sata, N., Newville, M., Rivers, M. L., Sutton, S. R., 2002. Molar volumes of molten indium at high pressures measured in a diamond anvil cell. Appl. Phys. Lett. 81, 1411-1413.

Siebert, J., Badro, J., Antonangeli, D., Ryerson, F. J., 2012. Metal-silicate partitioning of $\mathrm{Ni}$ and $\mathrm{Co}$ in a deep magma ocean. Earth Planet. Sci. Lett. 321, 189-197.

Siebert, J., Badro, J., Antonangeli, D., Ryerson, F. J., 2013. Terrestrial accretion under oxidizing conditions. Science 339, 1194-1197.

Solomatov, V. S., 2000. Fluid Dynamics of a Terrestrial Magma Ocean. Univ. Ariz. Press, Tucson, pp. 323-328.

Spice, H., Sanloup, C., Cochain, B., de Grouchy, C., Kono, Y., 2015. Viscosity of liquid fayalite up to 9 gpa. Geochim. Cosmochim. Acta 148, 219-227.

Stixrude, L., de Koker, N., Sun, N., Mookherjee, M., Karki, B., 2009. Thermodynamics of silicate liquids in the deep Earth. Earth Planet. Sci. Lett. $278,226-232$.

Stolper, E., Walker, D., Hager, B. H., Hays, J. F., 1981. Melt segregation from partially molten source regions: the importance of melt density and source region size. J. Geophys. Res. 86, 6261-6271.

Sun, N., Stixrude, L., de Koker, N., Karki, B. B., 2011. First principles molecular dynamics simulations of diopside $\left(\right.$ camgsi $\left._{2} \mathrm{O}_{6}\right)$ liquid to high pressure. Geochim. Cosmochim. Acta 75, 3792-3802.

Suzuki, A., Ohtani, E., Kato, T., 1995. Flotation of diamond in mantle melt at high pressure. Science 269, 216-218.

Syracuse, E. M., Abers, G. A., 2006. Global compilation of variations in slab depth beneath arc volcanoes and implications. $\mathrm{G}^{3}$ 7, Q05017. 
Tauzin, B., Debayle, E., Wittlinger, G., 2010. Seismic evidence for a global low-velocity layer within the Earths upper mantle. Nature Geoscience 3, $718-721$.

Thibault, Y., Walter, M. J., 1995. The influence of pressure and temperature on the metal-silicate partition coefficients of nickel and cobalt in a model C1 chondrite and implications for metal segregation in a deep magma ocean. Geochim. Cosmochim. Acta 59, 991-1002.

Tonks, W., Melosh, H., 1993. Magma ocean formation due to giant impacts. J. Geophys. Res. 98, 5319-5333.

Tschauner, O., Zerr, A., Sprecht, S., Rocholl, A., Boehler, R., Palme, H., 1999. Partitioning of nickel and cobalt between silicate perovskite and metal at pressures up to 80 GPa. Nature 398, 604-607.

Tucker, J. M., Mukhopadhyay, S., 2014. Evidence for multiple magma ocean outgassing and atmospheric loss episodes from mantle noble gases. Earth Planet. Sci. Lett. 393, 254-265.

Urey, H. C., 1947. The thermodynamic properties of isotopic substancess. J. Chem. Soc., 562-581.

Van Kan Parker, M., Sanloup, C., Sator, N., Guillot, B., Tronche, E. J., Perrillat, J.-P., Mezouar, M., Rai, N., van Westrenen, W., 2012. Neutral buoyancy of titanium-rich melts in the deep lunar interior. Nature Geoscience $5,186-189$.

Van Kan Parker, M., Sanloup, C., Tronche, E. J., Perrillat, J.-P., Mezouar, M., Rai, N., van Westrenen, W., 2010. Calibration of a diamond capsule cell assembly for in situ determination of liquid properties in the ParisEdinburgh press. High Pressure Res. 30, 332-341.

Wakabayashi, D., Funamori, N., 2013. Equation of state of silicate melts with densified intermediate-range order at the pressure condition of the Earths deep upper mantle. Phys. Chem. Minerals 40, 299-307.

Wang, Y. B., Sakamaki, T., Skinner, L. B., Jing, Z., Yu, T., Kono, Y., Park, C., Shen, G., Rivers, M. L., Sutton, S. R., 2014. Atomistic insight into viscosity and density of silicate melts under pressure. Nature Comm. 5, 3241. 
Weber, R. C., Lin, P.-Y., Garnero, E. J., Williams, Q., Lognonné, P., 2011. Seismic detection of the lunar core. Science 331, 309-312.

Wilke, M., 2005. Fe in magma - an overview. Annals Geophysics 48, 609-617.

Williams, Q., Garnero, E. J., 1996. Seismic evidence for partial melt at the base of Earth's mantle. Science 273, 1528-1530.

Wolf, A. S., Asimow, P. D., Stevenson, D. J., 2015. Coordinated hard sphere mixture (CHaSM): A simplified model for oxide and silicate melts at mantle pressures and temperatures. Geochim. Cosmochim. Acta 163, 40-58.

Yaoita, K., Katayama, Y., Tsuji, K., Kikegawa, T., Shimomura, O., 1997. Angle-dispersive diffraction measurement system for high-pressure experiments using a multichannel collimator. Rev. Sci. Instrum. 68, 2106-2110.

Yarger, J. L., Smith, K. H., Nieman, R. A., Diefenbacher, J., Wolf, G. H., Poe, B. T., McMillan, P. F., 1995. Al coordination changes in high-pressure aluminosilicate liquids. Science 270, 1964-1967. 
Highlights;

- methods to measure the density of magmas at high pressure are presented - compressibility mechanisms are discussed along with equation of states - magmas may be gravitationally trapped at depth

- magmas' structure and compressibility are linked with their ability to host trace elements 